\title{
Foreword: Whose creative industries?
}

\section{John Hartley ${ }^{1}$}

The context in which this book was produced is important, because there's a great deal more going on here than a simple observation of recent developments in an emergent economy. Lucy Montgomery has synthesized interdisciplinary approaches to the creative economy, media studies, copyright law and 'area' studies.

In an era of hyper-specialization it is unusual to find such a range of concerns, but at the same time it is impossible to do justice to specialist domains without knowing how they fit together, and how different national economic and cultural systems interconnect in a globalized economy and technologically networked culture.

\section{CONTEXT}

At QUT we have been among the pioneers of international research in the creative industries. In fact we launched the world's first Creative Industries Faculty in 2001, of which I was the foundation dean. But to achieve a preeminent research position we had to put together a team that drew on expertise in five separate disciplinary domains - media and cultural studies, law, business and economics, IT and computer science, and education.

In 2005 we won funding from the Australian Research Council for a Centre of Excellence based on this interdisciplinary mix, and went to work on a programme of research designed to:

1. account for the creative economy (what's special about it, economically, if anything?);

2. investigate various creative sectors, ranging from popular TV and film to fashion (what impediments are there on the pathway from creativity to market?);

3. ascertain what is needed to educate a creative workforce and wealth creators (in both formal and informal education);

4. experiment with prototypes of content creation and distribution, especially among non-specialist populations and socially disadvantaged groups; and 
5. promote the inclusion of creative innovation into national innovation systems, where policy settings in many countries at the time were heavily skewed towards bioscience, ICTs and nanotechnology (why do countries need a creative economy?).

Thus our research began to focus on problems at the intersection of culture and economy. On the cultural side was creative talent, both 'expert' (artists) and population-wide (consumer co-creation); and on the economic side were innovation and growth in a knowledge-based economy.

When we got started, the very term 'creative industries' was contentious, imprecise and of dubious provenance, having originated in the opportunistic hot-house atmosphere of political competition and local boosterism, rather than from any discernible first principles, either economic or cultural.

\section{POLICY}

An existing science did not develop a theory of creative industries that might then be tested using formal hypotheses, experiments, fieldwork, data-analysis and the like. Instead, government departments sought to benefit from the 'new' or 'weightless' information- or knowledge-based economy, ${ }^{2}$ from existing competitive advantage in certain industry sectors, especially in the UK, which boasted a large creative economy in the capital, and from seeking to redefine culture as an earning sector (growth) rather than a spending one (heritage, welfare).

All of this came together during the first New Labour government in the UK, when in 1998 culture minister Chris Smith sought to boost his portfolio's clout by yoking these 'heterogeneous ideas by violence together' (as if he were one of Dr Johnson's metaphysical poets), in order to get more support from the Treasury for culture.

The idea worked. You don't have to agree that it was a stroke of genius to admit that it was timely and productive and had far-reaching consequences, many unforeseen. Although the Treasury remained as flinty-hearted as ever, the 'creative industries' genie was unleashed from the knowledge-domain bottle, and Smith's department of Culture, Media and Sport (DCMS) gained first-mover advantage in defining the creative industries.

The important policy move here was to get culture away from the back door of the economy where it traditionally sat, tin cup in hand, crankily biting the hand that fed it, right around to the front and centre of innovation strategy, where suddenly it was revealed as a high-growth sector, outperforming other services (never mind sluggish manufacturing). It was dynamic and emergent, with multiplier effects on other sectors, a high rate of entrepreneurial initiative, 
and lots of start-ups, micro-businesses and sole traders, some of them - ageing rock stars - worth more than many large-scale companies.

\section{FLAWS}

One question did not even make it on to the agenda of a department whose main jobs were to spruik business and keep the arts lobby docile, and that was this: is it possible to have a 'creative economy' based on the creativity of the whole population, not just on existing artistic elites, professional designers and an 'expert pipeline' model of copyright-protected creativity?

There were other flaws in this policy initiative. First was the insistence that the creative industries, based as they are on individual talent, could prosper only in a world where intellectual property was strongly enforced. This left out of account the burgeoning world of consumer-created content and user-led innovation; and it forgot that creativity involves a lot of copying from past masters and contemporary competitors.

Second, it anchored the idea of the creative industries in the analogue era, where individual artists produced individual works either for public institutions or in a traditional marketplace dominated by single-platform firms (broadcasters, record labels, film studios, publishers, newspapers, fashion designers and so on). It missed out not only on the affordances of digital technologies, but more importantly on the internet ethos of 'knowledge shared is knowledge gained' and on the non-market or 'gift economy' aspect of social networking, crowd-sourcing and communities of affect.

Third was City of London hubris. After all, didn't the Brits have a worldbeater in the shape of the City's financial services industry? And wasn't London a great creative capital in showbiz, publishing, media, broadcasting and cultural tourism as well? So what could be more appropriate than to model an ambition for the creative industries on the success of financial services, Britain's biggest export: all market, no regulation (this was when the lighttouch FSA still seemed like a good idea); high levels of 'creativity' in product design (where the value-add is in the sophisticated inventiveness of products); high liquidity; high debt ('leverage'); and high compensation, all adding up to high-growth services. It all looked great as long as growth continued and credit was abundant. Surely the creative sector - like Pygmalion - could undergo a make-over and 'be like that'?

The creative sector certainly produced some winner-take-all celebrities, like J.K. Rowling and Damien Hirst, and both creative and high-tech winners made it to the under-40s Rich Lists. But that did not translate into a creative economy more generally, nor did the creatives out-compete the bankers on the Hertfordshire-mansion-buying circuit. The richest person in Britain was still 
the Duke of Westminster (property), later overtaken by Lakshmi Mittal (steel) and Roman Abramovich (oil).

And in any case, the City of London was in for a shock, in September 2008, when the head office of Lehman Brothers in the US phoned to say, 'London, you're on your own.' 4

A fourth weakness was its nationalistic bias. Everyone from the then UK finance minister Gordon Brown downwards believed that here was an example of 'competitive advantage' for the UK as opposed to other countries. All the talk was of how to lead the world, not join it. No one paused to wonder how countries might collaborate rather than compete in a globally networked system whose real motive force was located offshore.

Chris Smith's successor at the DCMS, Tessa Jowell, made speeches about how the UK could leave low-cost manufacturing to the Chinese and concentrate on high value-added creative goods and services. She forgot to mention that the Chinese themselves might have other ideas about that, and were listening carefully to foreign advisers (we were among them) who were telling them that they needed to shift from a low-cost 'made in China' economy to highvalue 'created in China', ${ }^{5}$ by growing their own creative sector, encouraging domestic consumption, and aspiring to turn around the 'creative trade deficit' where they imported more ideas from the West than they exported Chinese culture, media, branding and knowledge.

\section{TECHNOLOGY}

So while the creative industries initiative of the DCMS in the late 1990s was inspired, it was also self-serving and irrationally exuberant. The bubble obligingly burst in March 2000 with the dotcom crash, bringing the NASDAQ back from 5000 points to 1300 , where it languished for years.

Although a good many ICT ventures lost their money, the digital media and the internet did not go away, any more than railroads or automobiles had after previous stock-market crashes in the 1850s and 1930s. Nor did the creative industries suffer as much as other sectors with exposure to ICTs. However, it was a chastening experience to see how precarious creative enterprise could be, among both (venture) capitalists and (artistic) workers, once culture had been redefined in market terms rather than in those of heritage or subsidy.

By this time, in fact, it had become clear (not to everyone; the arts have more than their fair share of resistance-to-change curmudgeons) that high-tech ICTs - fat pipes - were going to be crucial to the creative sector, not the death of it. European-style 'analogue' creative industries and cultural institutions did not amount to much without US-style digital technologies and market-based new-media platforms. 
Here the European tradition of public culture and cultural institutions met the American tradition of individualism and the entrepreneurial ethos. Where 'Britart' artists might aspire to place their work in a museum (preferably the Tate Modern, Cool Britannia's latest tourist attraction), Californian computer geeks aspired to turn their string of code into a global corporation.

Was it possible to integrate these aspirations - intermingling artistry and entrepreneurship, individual talent and global scale, public culture and consumer demand, creativity and computing power?

In short, might digital technologies enable us to take creativity to population-wide participation and global scale? Did 'global media' have to imply 'monopoly control' by the usual suspects - Hollywood and international media moguls like Rupert Murdoch? Or could anyone get a look-in? If so, might smaller or emergent economies (say, Australia or China) benefit from technological advances and join in too?

Although 'big media' remained prominent as they migrated to the net, it was obvious from the start that online creativity could now also include a bottom-up, peer-to-peer element, since that's how the whole thing was invented in the first place. There was no reason in principle why such inventiveness had to be located in California.

\section{GEOGRAPHY}

Even so, California was a formidable competitor. Silicon Valley provided the model of a geographical creative cluster, where concentrating garage start-ups together seemed to make it easier for some of them to burgeon into global corporations in just a few years.

Richard Florida popped up to argue that the 'creative class' of knowledge professionals and ideas entrepreneurs was numerically small (only 150 million people worldwide), but it was disproportionately responsible for economic growth and creative innovation (which were increasingly the same thing). Its members included a lot more occupations than the traditional idea of creatives. There were the computer and mathematical geeks; architecture and engineering; life, physical and social-science occupations; education, training and library occupations; the arts, design, entertainment, sports and media.

These 'no collar' professionals, who also liked to live in an 'experience economy', were mobile and went where they liked, so you'd better make your city creative-friendly if you wanted to attract them. Florida's message struck a nerve with city planners worldwide, resulting in the surreal scene of mayors and bureaucrats puzzling over their 'creative class indexes' to see if they had enough students and gay people to make a viable creative city.

But could anywhere be a creative city? Even Florida didn't think so. 
Eventually he settled on 40-odd 'mega-regions' as the crucibles of global creativity: 'The places that thrive today are those with the highest velocity of ideas, the highest density of talented and creative people, the highest rate of "urban metabolism"” (The Atlantic, March 2009).

Most of them remain in the USA, according to Florida, but worldwide you can also find them in Europe (Greater London; Am-Brus-Twerp) and Asia (Greater Tokyo, China's Shanghai-Beijing Corridor, and India's Bangalore-Mumbai area).

\section{GROWTH}

At this point, with the convergence of telecommunications, computer and media technologies, it was possible to imagine content creation as a globally distributed user-created system. ${ }^{6}$ Everyone (with access to the web) could produce and publish their own media content, or share favourite stuff with their peers. Creative content converged with telecommunications. Instead of trying to make money out of unique items (this film, that painting), you could make it by promoting creative traffic among peers who made the creative content for themselves.

In other words, once the World Wide Web could handle video (by 2005), it was possible to imagine how something like BitTorrent or YouTube might replace broadcasting as the 'platform' for creative media - not one-to-many mass entertainment but 'many-to-many' messages (more like telecoms than media).

'Platform' is the wrong metaphor here, implying something stable upon which to build the castle where - as they said at the time - 'content is king'. The speed of change on the technical side continued to obey Moore's Law growth was faster than exponential, doubling the extent of creative infrastructure, speed, connectivity, users, uses and content every couple of years. And of course much of the resultant content was shared, pirated, unpaid or amateur, making it very hard to erect a viable business plan over any new platform.

This produced further uncertainty and dynamism in creative enterprise. This year's hot new platform or 'killer app' was next year's landfill - thereby giving rise to a not altogether welcome new 'creative industry', that of processing e-waste, in which the Chinese town of Guiyu in Guandong is a world leader. ${ }^{7}$ Intel's business plan assumed that the most successful product of the forthcoming financial year would be something that had not yet been invented. They maintained a research budget the same size as Australia's to make sure the invention was theirs.

Continuing growth was driven by technological innovation, by the extension of digital participation across an ever-wider population, and by the 
burgeoning uses to which all this capability could be put, both within businesses and in informal social networks.

One very interesting aspect of this growth was how it outpaced public policy settings. Although (as ever) crucial technological breakthroughs were part-funded by the defence industry, most of the energy came from nongovernment agencies, some set up for profit and many not.

When public policy did catch up - in the shape of the 1998 DCMS initiative - it focused exclusively on economic growth, as a sort of updated industry policy. It was not focused on the wider and more important question of the growth of knowledge. ${ }^{8}$

Thus, relatively little public investment was made in the propagation of digital take-up across populations, in education for digital literacy, or in support for creative development and organization (other than business services for creative firms).

In the nineteenth and early twentieth century, modernizing countries had invested vast public resources in achieving universal print-literacy, but no such effort was contemplated in relation to digital media. As far as the growth of knowledge via computers, telecommunications and media networks went, 'the people' were on their own.

\section{SOCIAL NETWORKS}

In short, the growth of knowledge was a problem not for the government but for the market - and that was government policy. If people wanted a creative economy benefiting from global digital technologies, and if individuals wanted to hook up with like-minded others worldwide, then they must 'do it themselves'.

The dotcom crash and the digital revolution emboldened some to say that the problem had been caused not by too much creativity but too little. Attention had been focused too narrowly on connectivity and the use of IT for internal business operations. What might the population at large like to do with this network? Enter DIY culture, Web 2.0 and the new global players, Google, Facebook, YouTube, Wikipedia and Flickr.

Here the true nature of the creative economy crystallized in a way that had not been clear till now. The creative industries were not the 'copyright' industry; they were not the 'arts' industry; they were not creative 'professions' (designers, media producers and so on); they were not the 'media industries'. The creative industries were characterized by something rather different: they were - and are - social network markets. ${ }^{9}$

Social network markets have two main peculiarities. The first is that people's choices are determined by the choices of others in the network. The 
second is that choices are status-based. Why are these characteristics peculiar?

1. Markets are supposed to be based on self-interested choice, which is assumed to be individualist and rationalist, not determined by the choices of others. In social network markets choice is externalist or system-based, produced by relationships, not reason - reason is the outcome of collective choices in a system of relations, not an input.

2. Choice is meant to satisfy wants or needs. But in social network markets it expresses status relations. Thus, the creative industries don't look very much like a neoclassical market. The choices of high-status celebrities will often be preferred, and those of low-status people avoided, creating a market in celebrity endorsement. Celebrity itself is not a product of, but an input into, such a market. Emma Watson can make Burberry cool again; but she had to be Emma Watson first.

'Entrepreneurial consumers' too can gain status by making admired choices (not just in high fashion but also in street fashion, such as Harajuku in Japan). ${ }^{10}$ And because status is both relative and transient, the continuing process of making choices in social networks has an impact on status and thus on values (and further choices), both cultural and economic.

This is what Jason Potts calls 'choice under novelty' as opposed to choice under uncertainty or choice under risk, both of which have been studied in behavioural economics. ${ }^{11}$ When faced with new knowledge, new connections or new ideas, people cannot reduce uncertainty by getting more information, precisely because what they're facing is new. Thus, suggests Potts, 'rational economic agents' - that's everyone - observe and learn from how others are making choices, and thus how to respond to the new. This is how they get into social network markets in the first place. Once there, observing and connecting with others, not least by random copying, ${ }^{12}$ new possibilities open up, including other opportunities for 'consumer productivity' and co-creation.

Further, much of what constitutes social networks, and therefore the creative industries, is not market-based at all, at least not in the usual sense. This is because social networks exist prior to and outside of markets (among families, friends, neighbours, enemies and so on), and because they belong to the 'economy of attention' as much as to the monetary economy. ${ }^{13}$

People place value on the attention they give and receive. This is an economy of signals as much as one of monetary values, which is why it needs a 'convergence' of cultural studies (semiotics, anthropology, media analysis) with economics to make sense of what's going on. ${ }^{14}$ People may invest time, creativity and material resources in creating the right signals to attract more attention. They also value paying attention to favoured others. Fans, for 
instance, invest in the attention they offer to their idols. Attention may be 'paid' in many ways, not all of them monetized. Choice may just as easily end in a marriage or friendship as a sale.

\section{CONSUMERS $=$ PRODUCERS}

The very concept of a consumer is irrelevant in social networks. Self-organizing networks of people, who are in it for the value of the relationship with others, are not really consuming anything. Quite the reverse. What's important is not what they buy, but what they make and how they signal, whether that's simply 'making sense' of stuff they like, or making contact with each other, or making their own creative content, from photos or text to competitive gaming strategies or open-source code. The erstwhile 'consumer' is now the focus and engine of the productivity of the system.

Social networks are not made of passive consumers waiting to be persuaded whether to buy the blue one or the white one, or push this button rather than that. They are strictly peer-to-peer, self-created and sustained, multi-nodal and mutually interconnected networks, not the end-point of a linear product pipeline. A ballistic strategy, where you 'target' this or that consumer profile and then 'bombard' it with well-aimed messages, is also wrong-footed. ${ }^{15}$

In a social network market you can't make choices for the consumer. The whole point is that users are doing the social networking for themselves. In essence this is a socio-cultural rather than an economic activity. What people are doing is about their status, and those they admire (or otherwise), including their own personal identity-forming activities and people in their own private circle.

\section{CREATIVE DESTRUCTION}

From this perspective - the perspective of the DIY user or 'productive consumer' - the status of organizations is not all that crucial. People interact with content and with others, not with firms. Maybe that's why people don't think of sharing as piracy - they don't see themselves as being in a proprietary environment.

It is easy to see that established distinctions between producer and consumer, public and private, property and piracy, expert and amateur, and agent and institution are undergoing a thorough process of Schumpeterian 'creative destruction'. This is 'remix culture' with a vengeance. ${ }^{16}$

In this context it is unwise even to hang on to 'the firm' as the obvious unit of agency or enterprise, since firms are by no means the only (certainly not the first) source of innovation in the online environment. Other forms of association, organization and institution have been established, from self-selecting 
networks of mutual interest to giant enterprises based on attention (Perez Hilton), the gift economy (Project Gutenberg), corporate branding (MIT's free courseware) or friendship (not just Facebook).

Many of these start out as amateur hobbies (genealogy), which subsequently prove robust enough to sustain both commercial and community forms of organization. In these kinds of networks, firms co-exist symbiotically with community networks. Very often the 'generative edge' of a new affordance is not motivated by profit, but unforeseen popularity may create a market which firms can stabilize.

In other words, there's an evolutionary process where the necessary variation and experimentation precede selection (firms), adoption (markets) and retention or extinction (competition). Thus the system as a whole is larger than the market aspect of it, and includes more kinds of enterprise than the firm, and more kinds of motivation than profit or price incentives.

So here's another peculiar thing. If, as government departments and industry analysts tend to do, you focus exclusively on the producer end of an industry, then you're likely to miss the creative industries altogether. They cannot be deciphered by looking at what firms do, only by looking at what people do, especially when they are interacting within very large-scale open complex systems.

But at the same time it's no good reducing 'people' to the status of an atomized and individualist 'self-contained globule of desire' (in Thorstein Veblen's words). ${ }^{17}$ Individual identity is itself a social project, produced in and by the systems, institutions, networks and relationships in which they participate, all the way up from family and oral language to mass-mediated celebrity.

When you consider the 'identity' of global celebrities - let's say Paris Hilton - it is clear that this identity is a constantly produced work in progress, and that Ms Hilton is more like a global brand or firm than an individual. Of course, as a winner in the economy of attention she has amassed myriad more networked connections than 'ordinary' consumers, which means that in Barabasi's terms she's a 'hub' rather than a 'node'. ${ }^{18}$ She's a spike and you're part of the 'long tail' on a 'power law' curve of attention connections in a 'scale free network'. Or, to put it another way, everyone is part of this interconnected network. Thus, despite individual difference between Paris Hilton and those who live 'the simple life', the identity of all is a product of connections in the same dynamic system. ${ }^{19}$

\section{RADICAL RETHINK}

To proceed on a business-as-usual business plan, where the script says that if firms target consumers then industry prospers, prematurely closes down the transformational potential of the times. 
Instead of this, and precisely because we seem to have entered a topsyturvy world where it is no longer clear what anything means, we need to take a good hard look at how open complex systems work, and what the role of creativity - not to mention industry - may be in that context.

As mentioned at the outset, this is exactly what the Centre of Excellence for Creative Industries and Innovation (CCI), funded by the Australian Research Council (ARC), has set out to do. As we've grappled with these issues over the years, it has become increasingly clear that we need a radical rethink about first principles.

As part of the work of the CCI, I have been engaged in a five-year 'Federation Fellowship', also funded by the ARC, to investigate 'the uses of multimedia'. My own research interest has been in what happens to previously popular media, especially broadcast television, in the digital and interactive era, and what could happen with population-wide digital literacy if you take the internet to be as significant an invention as printing was in the early modern period (which I do). My books Television Truths (Wiley Blackwell, 2008) and The Uses of Digital Literacy (University of Queensland Press, 2009) pursue these questions.

Printing with movable type was initially used (from the 1450s) for ecclesiastical and state purposes. Inadvertently, however, by the seventeenth century it had enabled the society-wide adoption of realism through three great textual systems, all of which required printed books and periodicals. These were science, journalism and the novel.

Given that history of unforeseen consequences and an out-of-all-proportion growth of knowledge resulting from the adoption of a new communications technology, what might be the consequences of interactive computer-based communications and the concomitant spread of digital literacy?

It still is too soon to tell, but it is obvious that we ought not to be thinking about the instrumental purposes of the opening players.

Lucy Montgomery has been one of three post-doctoral fellows working on the Federation Fellowship team, during which period she has written this book. The other post-doctoral fellows are Jean Burgess and John Banks. Jean Burgess works on 'vernacular creativity', and her co-authored book on YouTube: Online Video and Participatory Culture was published by Polity Press in 2009. John Banks has been studying the relationship between games companies and players, observing the 'community relations' aspect of games companies. Here the whole question of user-created content, and the distinctions between producer and consumer, expert and amateur, become life-ordeath issues ... for the games company. If its player community don't like a game, and the games developers won't listen, the company may founder. Banks's book Making Co-creative Culture: Videogames and Social Network Markets will be published in 2010-11. ${ }^{20}$ 
Our project benefited from contact with specialists in other fields, especially Centre fellows Jason Potts (evolutionary economics), Michael Keane (China's creative economy and policy) and Brian Fitzgerald (copyright and intellectual property law). During the course of our work, which also features decisive contributions from the sinologist-economist Carsten Herrmann-Pillath (Frankfurt School of Finance and Management), it has become increasingly clear that we can't just accept the definition of the creative industries at the going rate. There had to be a revaluation (see http://cultural-science.org).

\section{HISTORY}

We started this off by historicizing the very idea of the creative industries. It did not emerge from a definition, but from a situation, and therefore the idea as an 'artefact' is not scientific but historical. Thus, in Creative Industries (2005) and in Hartley (2009), I posited that the creative industries could already be seen as a dynamic, evolving concept even during the decade or so of its current usage. ${ }^{21}$

But before we get to that, a longer history needs to be acknowledged, going back to the Enlightenment (and thence to Classical antecedents). The public function of creative and cultural practices is constantly reinvented for each new era, so that the stage on which the creative industries debuted was already crowded with dramatis personae:

- From the Enlightenment notion of liberal arts and civic humanism (the public virtue of the gentleman) comes the idea of the creative arts as noble, civilizing, uplifting and aristocratic; 'noblesse oblige'.

- From the nineteenth-century rise of the nation state came the idea of national culture and public arts, when European aristocrats turned their pictures over to national galleries and their palaces into museums.

- From industrial culture, especially in America, came the idea of popular arts - fiction, cinema, media - based in the marketplace, not the public institution, giving rise to the citizen-consumer as an amalgam of democratic values (freedom, public) and capitalist ones (comfort, private) - Walt Whitman and Wal-Mart.

- From modernism and the artistic avant-garde came the idea that creativity equals 'the new' and that anything produced at mass scale is a mere reproduction, thereby recasting aristocratic elitism into intellectual elitism, where the newest idea rules.

- From the Frankfurt School and anti-capitalist leftist academics came the idea of the culture industries, where media and state power were 
coterminous and the state was controlled by capital; creative 'industries' were but a capitalist mouthpiece.

- Regional policy depoliticized the idea of the cultural industries and sought to attract them to set up in this or that country or city, resulting eventually in the idea of 'cultural capitals' and 'media capitals'.

- From the information industry came the idea of creativity as part of the 'weightless', new or knowledge economy, adding high-value creative content to information infrastructure and connectivity, making creative 'inputs' part of value-added services or intangibles.

All of these traditions were in place - and some of them in contention with each other - when Chris Smith had his good idea that the creative industries were an emergent economic sector. Now the question became: what kind of economic sector was it?

\section{EVOLUTION}

Not surprisingly in such a fast-moving and turbulent context, the very idea of what constitutes the creative industries is equally dynamic. Barely a decade on, the concept has shown three distinct phases over its short life. Each phase designates a different field of creative practice, each wider than and encompassing the one before. Thus you might model the creative industries idea as a virus, spreading through a population via various hosts until everyone is infected with it.

The phases are:

\section{Creative clusters (industry) - closed expert system}

The first phase is the industry definition (DCMS), which I call 'creative clusters'. It is made of clusters of different 'industries' - advertising, architecture, publishing, software, performing arts, media production, art, design, fashion and so on - that together produce creative works or outputs. This is a 'provider-led' or supply-based definition. The sector is reckoned to be anywhere between 3 and 8 per cent of advanced economies, and claimed to be high-growth, with an economic multiplier effect.

Looked at this way, the creative industries are nothing other than firms whose livelihood depends on creating intellectual property and protecting it with copyright, enforced against both commercial copying and consumer 'piracy'. It is thus modelled on the industrial-era closed expert pipeline (invent - patent/copyright - manufacture - distribute - sell), preferably with all of these functions controlled by the one firm. 


\section{Creative services (economy) - hybrid system}

The second phase is the services definition, which I call "creative services'. It is characterized by the provision of creative inputs by creative occupations and companies, most obviously where professional designers, producers, performers and writers add value to firms or agencies engaged in other activities, from mining or manufacturing to health, government and other public services. ${ }^{22}$ By one estimate, creative services expand the creative industries by at least a third. ${ }^{23}$ Again, the input is high value-add; indeed, it is thought to add value to the economy as a whole, boosting the profitability of otherwise static sectors.

It is this kind of creativity that transforms old-style services like transport into creative services like 'experience'-based tourism. Because this version of the creative industries is economy-wide and involves occupations and agencies other than firms, it may be regarded as a hybrid system, in which social networks play a role, but it remains focused on market-driven activity; it is 'demand-led' only in a b2b environment. Nevertheless here is where innovation policy can gain traction, encouraging firms of all kinds to collaborate with creative entrepreneurs and to innovate using creative inputs.

3. Creative citizens (culture) - open innovation network

The third phase is the cultural definition, which I call 'creative citizens'. Here is where creativity spills out of the economy, being an attribute of the population at large - the workforce, consumers, users and entrepreneurs, who become hard to distinguish from artists in how they go about pursuing an idea and creative reputation and a market for it. This is a userled or demand-side definition. The expansion of the creative industries to cover everyone (at least in principle) allows the possibility that the energies of everyone in the system can be harnessed, adding the value of entire social networks and the individual agency of whole populations to the growth of knowledge.

Such a vastly expanded definition of creative agency is only 'thinkable' with complexity/network theory and the notion of open complex systems. It is most easily evident in computer-based social networks, but is not confined to the digital domain. Creative citizens are 'navigators' rather than 'consumers'; they may also act in concert as 'aggregators' to produce 'crowd-sourced' solutions to creative problems.

Following this line of thought it is easy to see that there's more to creativity than what is taught in art schools - or business schools. Creativity is generalized as a population-wide attribute, it requires social networks, and its 'product' is the growth of knowledge, sometimes within a market environment, sometimes not. 
This is a radically democratic move, although it is far from universally adopted and its implications have barely begun to be worked through. But it is possible to identify the new value propositions associated with an evolved and expanded notion of population-wide creative industriousness in this formula:

Agents (both professional and amateur)

+ Network (both social and digital)

+ Enterprise (both market-based and other forms of purposeful association)

$=$ Creative value (in a complex open system)

= Growth of knowledge

\section{MORE MODELS}

This 'social network markets' model of creative industries was first elaborated in an article by Jason Potts and others in 2008. ${ }^{24}$ It continues to form the basis of the work we're doing at the CCI, and it is given further evidential substance here in Lucy Montgomery's book.

A different model, seeking to account for the creative economy along a different line of thought, was published by Potts and Cunningham at around the same time. ${ }^{25}$ Instead of showing the phases by means of which creativity ripples out from industry, via economy, to culture (and back again), this approach sought to show that differing economic theories and approaches brought a different model of the creative industries into view. The four models are:

1. welfare (market failure model of culture), requiring a negative policy of welfare subsidy;

2. competition (nothing special here), requiring a neutral or standard industry policy;

3. growth (creative industries as a dynamic sector-DCMS-style), requiring a positive investment and growth policy;

4. innovation (creative industries as general dynamic of change), requiring an evolutionary policy of innovation.

All of this modelling is characterized by one major concern - the role of creativity in change, both cultural and economic, and its location as a property of agency in open complex systems ('networks'). ${ }^{26}$

The creative industries were looking less like a small but sexy sector in affluent economies, ${ }^{27}$ and more like a general social technology for enabling change.

It may even be argued that the 'creative industries' are the empirical form 
taken by innovation in advanced knowledge-based economies. This would place creative innovation on a par with other enabling social technologies like the law, science and markets. The creative industries may be regarded as the social technology of distributed innovation in the era of knowledge-based complex systems. $^{28}$

Whichever way you looked at it, we were heading for an evolutionary approach to culture in general. Modelling not just the economy but also culture as evolutionary, and seeing creativity as part of the general process of innovation and adaptation to change, has led us towards a new kind of intellectual enterprise that goes under the heading of 'cultural science'.

\section{THROWING BRICKS}

But just before we get to that, it is worth bringing geography back into the picture. If the creative industries can be seen in terms of 'social network markets', then any industry has to go through a 'creative industries' phase at some point, because the creative industries 'involve the creation and maintenance of social networks and the generation of value through production and consumption of network-valorized choices in these networks' ${ }^{29}$

Thus there is a development aspect to creative industries thinking, because, if adaptation to change, access to technologically enabled digital networks, and the production and consumption of network-valorized choices among a creative population do constitute the creative industries, then developing and emergent economies need them more than anyone.

Furthermore, without being encumbered by industrial-era investment in smoke-stack industries and rust-belt regions, emergent countries may aspire to become 'leapfrog economies', using the creative industries as a social technology of modernization, global engagement and urban development. ${ }^{30}$ This stimulates their SME and NGO sectors and promotes the development of indigenous micro-business.

It also helps to develop the most abundant resource available to developing countries, creative human capital, especially with their predominantly young populations. For young people especially, creative expression is itself an attractant to enterprise. In developing countries, a creative economy is also a powerful tool for promoting and valorizing diversity, of both population and cultural expression, both traditional and modern. Thus creative industries are the generative edge of innovation among the billion or so young people worldwide who are now moving through their teenage years towards full economic productivity.

That is why it is just as important to consider countries like China as the USA or UK - indeed the model of creative industries inherited from the latter 
may be disastrous for emergent economies, based as it is on analogue technologies like painting or the record industry.

Thus whatever model of the creative industries is adopted, it needs to take account of the 'creative destruction' that may imminently be wrought on the global economic and cultural scene by the BRICKS countries - Brazil, Russia, India, China, Korea, South Africa - and, one may add, Indonesia (and many others - this being the point).

Lucy Montgomery's book is one of the first to take the idea of the creative industries and work through it in the context of an emergent economy - in this case the strategically crucial one of China.

\section{COPYRIGHT CONFLICT}

In a context such as this, it is unwise to carry forward a definition of the creative industries that is based on record-label and Hollywood notions of copyright. Militant enforcement of owners' IP rights and anti-networking stratagems like DRM are predictable responses by existing investors, but that doesn't make them good policy for new ones. ${ }^{31}$

But at the same time it is obvious that commercial value requires that you have something to sell, and if that something is an idea there has to be a way to monetize it. Hence there is no escaping the fact that copyright and intellectual property are the point of tension for contemporary cultural, creative and commercial conflicts for the foreseeable future.

Here is where old and emergent enterprises clash, and, if the overall 'growth of knowledge' is the ultimate object of study, then the real and contentious questions of who owns that knowledge, how it can be shared, through what media of distribution, and accessible by whom (and on what terms) are very pressing.

Yet neither economics nor cultural studies have thought as carefully as they should about the problem of copyright. It's not an old-style 'Left v Right' struggle between libertarian progressives and control-culture reactionaries (though it does look like that sometimes). It is a problem of how to coordinate and organize innovation, dynamism and change in an existing complex system without snuffing out either the system or the change.

\section{CULTURAL SCIENCE}

And so it is more important than ever to get a clear idea of what's going on. Within the flux of change and differences of approach, opinion and purpose, it is never going to be possible to derive an analytical understanding from mere 
observation of the immediate to-and-fro of policy, debate, promotion and critique. However, it is equally clear that continuing to approach the creative industries using existing templates - whether by means of business plans, public policy or academic disciplines - will miss much of what has been described above.

This is what has led us to a work in progress that we're calling 'cultural science'. It is an evolutionary approach to both culture and the economy, combining evolutionary economics, cultural studies, and complexity or network studies. It seeks to investigate the growth of knowledge. It sees cultural and biological systems as co-evolutionary, and sees culture as a complex open adaptive system.

An immediate problem is that the fields closest to the study of creativity, including media studies, cultural studies, area studies (that is, the cultures and languages of particular countries) and various branches of the social sciences, have been among the very fields most resistant to 'taking the evolutionary turn' in relation to their object of study. Furthermore, the traditional 'two cultures' distinction between science and the humanities, and the lack of numeracy among many of the latter serve to make empirical studies of complex evolving systems hard to attempt.

There are equally gaping holes in the knowledge, skills and aptitudes of those coming to creativity and culture from economics or the sciences. They can do circulation, but they're not so astute about meaning. On both sides there is a tendency to adopt a 'heads down' attitude to concentrate on the microscale of local and familiar problems, leaving the macro-scale of systemic coordination, hierarchy, growth and interconnection with other systems out of the analytic picture.

Just because the phenomena under observation are both dynamic and multivalent, it is therefore necessary to move from single-discipline research to problem-solving research, from solo hyper-specialization to team-based collaboration, and from national silos to international research networks. Most importantly, it is necessary to develop a coherent conceptual and theoretical framework through which to advance from an observational to an analytical approach.

Since embarking on this adventure, those of us pursuing a cultural science approach have become more firmly convinced that this is worth pursuing by finding that - under various banners - plenty of others are pursuing it too. There are well-established programmes of research into cultural and biological co-evolution in anthropology, language, neuroscience, economics and even social science. ${ }^{32}$ More recently, evolutionary studies of stories, art and technology have been published. ${ }^{33}$ The use of complexity studies and game theory to model and analyse social networks (both analogue and digital) is well advanced. ${ }^{34}$ Cultural science is but one strand in this general current, and very much in its infancy. 
However, it is worth the effort not only to find out how the growth of knowledge works, but also for more immediate gains. Those trained in the humanities have found it hard to make an impression on public policy formation or engagement with business, especially in relation to innovation. It is hard to persuade policymakers and business strategists to take creativity seriously without systematic and numerate evidential data to back up any claims.

Thus, while many agree that it is vital to add the cultural and human sciences to national R\&D investment, to add creativity to science, technology, engineering and medicine (STEM) as an integral part of the innovation system, and to foster creative ideas as well as going for the technical fix, none of this will happen if those who are interested in culture and creativity can't speak the same language as those who are interested in the growth of both the economy and the knowledge base.

In the meantime, opportunities are being wasted, by government, business and cultural experts alike, to make better use of our growing understanding of the interfaces between cultural and economic values, between ideas and markets, between users and technologies, between elite expert systems and consumer populations, and between emergent and mature national systems.

\section{READ ON}

This is the interdisciplinary context in which Lucy Montgomery's book fits. She has pursued practical questions with this context in mind, while seeking as far as is currently possible to adopt an approach that aligns with cultural science as it unfolds. The result is a forward-thinking book that looks at China in a new way and comes up with some new questions.

China's Creative Industries provides a coherent argument with real drive and purpose. It advances our theoretical and conceptual understanding of the creative industries, of intellectual property, and why these things need to be thought about differently. It shows why China is important to the overall situation and not just a regional application. I really like the build-up of concepts, from 'entrepreneurial governmentality' and the 'entrepreneurial consumer' to a reworked notion of intellectual property that applies not only to China.

This book adds substance to our team's earlier conceptual work, joining the agenda-setting publications mentioned above as part of a coherent intellectual programme.

Together with further work by Potts, Banks, Burgess, Herrmann-Pillath and others, Lucy Montgomery's book also adds substance to our 'cultural science' claims. We have moved beyond the merely observational (I went to China/the games industry/fashion and saw this activity, spoke to that individual) to the properly analytical. 
Whether you're interested in economic, cultural, technological, Chinese or copyright issues, I commend China's Creative Industries: Copyright, Social Network Markets and the Business of Culture in a Digital Age to your attention. As Montgomery demonstrates, the problem of indeterminacy in how we understand the creative industries that I have tried to elaborate above - the question 'Whose creative industries?' - does have one emergent but clear answer: China's creative industries.

\author{
John Hartley, AM
}

Brisbane 2010

\title{
NOTES
}

1. John Hartley, AM, is Australian Research Council (ARC) Federation Fellow and Research Director of the ARC Centre of Excellence for Creative Industries and Innovation at Queensland University of Technology (QUT). Prior to that he was foundation dean of the Creative Industries Faculty at QUT and foundation head of the School of Journalism, Media and Cultural Studies at Cardiff University. The author of 20 books and many articles in the fields of media and creative industries, he is a Fellow of the Australian Academy of the Humanities and editor of the International Journal of Cultural Studies.

2. C. Leadbeater (1999), Living on Thin Air: The New Economy, London: Viking.

3. See www.reelclassics.com/Musicals/Fairlady/lyrics/fairlady-whycantawoman.htm.

4. See: http://everythingneednotfit.blogspot.com/2008/10/betrayal-of-london-unheard-innew-york.html.

5. M. Keane and J. Hartley (eds) (2006), International Journal of Cultural Studies, 9 (3) (September), special issue on Creative Industries and Innovation in China; M. Keane (2007), Created in China: The Great New Leap Forward, London: Routledge.

6. H. Jenkins (2006), Convergence Culture, New York: NYU Press.

7. See 'Electronic Waste' and 'Electronic Waste in Guiyu' (Wikipedia); and www.chinapix.com/multimedia/guiyu/.

8. B. Loasby (1999), Knowledge, Institutions and Evolution in Economics, London: Routledge; and see J.S. Metcalfe and R. Ramlogan (2005), 'Limits to the Economy of Knowledge and Knowledge of the Economy', Futures, 37 (7), 655-74.

9. J. Potts, S. Cunningham, J. Hartley and P. Ormerod (2008), 'Social Network Markets: A New Definition of the Creative Industries', Journal of Cultural Economics, 32 (3), 167-85.

10. J. Hartley and L. Montgomery (2009) 'Fashion as Consumer Entrepreneurship: Emergent Risk Culture, Social Network Markets, and the Launch of Vogue in China', Chinese Journal of Communication, special issue: China: Internationalising the Creative Industries, 2 (1), 61-76. And see www.japaneselifestyle.com.au/tokyo/harajuku_fashion.htm.

11. J. Potts (forthcoming), 'Can Behavioural Biases Explain Innovation Failures? Toward a Behavioural Innovation Economics', Prometheus.

12. See R.A. Bentley (2009), 'Fashion versus Reason in the Creative Industries', in M. O'Brien and S. Shennan (eds), Innovation in Cultural Systems: Contributions from Evolutionary Anthropology, Boston, MA: MIT Press, pp. 121-6.

13. Richard A. Lanham (2006), The Economy of Attention, Chicago: Chicago University Press.

14. C. Herrmann-Pillath (2010), The Economics of Creativity and Identity: A Cultural Science Approach, St Lucia: University of Queensland Press.

15. Hence the change in marketing ideologies, towards 'viral', 'groundswell' and 'herd' conceptualizations of marketing communication. See C. Li and J. Bernoff (2008), Groundswell: Winning in a World Transformed by Social Technologies, Boston, MA: 
Harvard Business School Press; and M. Earls (2007), Herd: How to Change Mass Behaviour by Harnessing Our True Nature, London: John Wiley.

16. L. Lessig (2008), Remix: Making Art and Commerce Thrive in the Hybrid Economy, London: Bloomsbury, www.bloomsburyacademic. com/remix.htm.

17. T. Veblen (1898), 'Why Is Economics Not an Evolutionary Science?', Quarterly Journal of Economics, 12, http://socserv.mcmaster.ca/econ/ugcm/3113/veblen/econevol.txt.

18. A.-L. Barabasi (2003), Linked: How Everything Is Connected to Everything Else and What It Means, New York: Plume.

19. Paris Hilton's reality TV series The Simple Life (2003-07) won her the 'Innovator Award' at the 2009 Fox Reality Awards.

20. See also J. Banks and J. Potts (2010), 'Co-creating Games: A Co-evolutionary Analysis', New Media and Society, 12 (2), 253-70.

21. See J. Hartley (2005), 'Creative Industries', in J. Hartley (ed.), Creative Industries, Malden, MA and Oxford: Wiley-Blackwell, pp. 1-40; and J. Hartley (2009), 'From the Consciousness Industry to Creative Industries: Consumer-Created Content, Social Network Markets and the Growth of Knowledge', in J. Holt and A. Perren (eds), Media Industries: History, Theory and Methods, Malden, MA and Oxford: Wiley-Blackwell, pp. 231-44.

22. The first proponent of this view of the creative economy was John Howkins: see J. Howkins (2001), The Creative Economy: How People Make Money from Ideas. London: Penguin.

23. See P. Higgs, S. Cunningham and H. Bakhshi (2008), Beyond the Creative Industries: Mapping the Creative Economy in the United Kingdom, London: NESTA, www.nesta.org.uk/library/documents/beyond-creative-industries-report.pdf.

24. J. Potts, S. Cunningham, J. Hartley and P. Ormerod (2008), 'Social Network Markets: A New Definition of the Creative Industries', Journal of Cultural Economics, 32 (3), 167-85.

25. J. Potts and S. Cunningham (2008), 'Four Models of the Creative Industries', Cultural Science Publications, http://cultural-science.org/FeastPapers2008/StuartCunningham Bp.pdf.

26. See J. Potts (2008), 'Creative Industries and Cultural Science: A Definitional Odyssey', Cultural Science Journal, 1 (1), http://cultural-science.org/journal/index.php/ culturalscience/article/view/6/15. Potts found 17 models!

27. E. Currid (2008), The Warhol Economy: How Fashion, Art, and Music Drive New York City, new edition, Princeton, NJ: Princeton University Press.

28. J. Hartley (2009), 'From the Consciousness Industry to Creative Industries: ConsumerCreated Content, Social Network Markets and the Growth of Knowledge', in J. Holt and A. Perren (eds), Media Industries: History, Theory and Methods, Malden, MA and Oxford: Wiley-Blackwell, pp. 231-44.

29. J. Potts (2008), 'Creative Industries and Cultural Science: A Definitional Odyssey', Cultural Science Journal, 1 (1), http://cultural-science.org/journal/index.php/ culturalscience/article/view/6/15, Definition no. 12. See also J. Potts (2009), 'Do Developing Economies Require Creative Industries? Some Old Theory about New China', Chinese Journal of Communication, 2 (1), 92-108.

30. See UNCTAD (2008), Creative Economy Report 2008: The Challenge of Assessing the Creative Economy towards Informed Policy-Making, www.unctad.org/creative-economy.

31. J. Potts and L. Montgomery (2009), 'Does Weaker Copyright Mean Stronger Creative Industries? Some Lessons from China', Creative Industries Journal, 1 (3), 245-61.

32. For instance the Centre for the Coevolution of Biology and Culture at Durham University (www.dur.ac.uk/ccbc); and see P. Richerson and R. Boyd (2005), Not by Genes Alone: How Culture Transformed Human Evolution, Chicago: Chicago University Press; A. Mesoudi (2007), 'A Darwinian Theory of Cultural Evolution Can Promote an Evolutionary Synthesis for the Social Sciences', Biological Theory, 2 (3), 263-75; J. Hurford (2007), The Origins of Meaning, Oxford: Oxford University Press; P. MacNeilage (2008), The Origin of Speech, Oxford: Oxford University Press; D. Bickerton (2009), Adam's Tongue: How Humans Made Language, How Language Made Humans, New York: Hill \& Wang; W.G. Runciman (2009), The Theory of Cultural and Social Selection, Cambridge: Cambridge University Press. 
33. See Y. Lotman (2009), Culture and Explosion, Berlin: Mouton de Gruyter; B. Boyd (2009), On the Origin of Stories, Cambridge, MA: Harvard University Press; D. Dutton (2009), The Art Instinct: Beauty, Pleasure and Human Evolution, London: Bloomsbury; B. Arthur (2009), The Nature of Technology: What It Is and How It Evolves, New York: Free Press.

34. Most obviously in the work of the Santa Fe Institute; see also E. Beinhocker (2006), The Origin of Wealth: Evolution, Complexity, and the Radical Remaking of Economics, Boston, MA: Harvard Business School Press; K. Sawyer (2005), Social Emergence: Societies as Complex Systems, Cambridge: Cambridge University Press; R.A. Bentley and P. Ormerod (2010), 'Agents, Intelligence, and Social Atoms', in M. Collard and E. Slingerland (eds), Integrating Science and the Humanities, Oxford: Oxford University Press; P. Ormerod (2007), Why Most Things Fail: Evolution, Extinction and Economics, London: Wiley. 